\title{
Os Romances de Pepetela e a Imaginação \\ da NaÇão em Angola
}

Frank Marcon*

marconfrank@hotmail.com

Resumo: Neste artigo, analiso a relação entre o escritor Pepetela, seus romances e a imaginação da nação em Angola. Procuro demonstrar como a trajetória de vida do escritor e sua relação com a União dos Escritores Angolanos fazem parte de um contexto de institucionalização da literatura naquele país, bem como procuro analisar os romances e sua relação com a criação de uma narrativa histórica romanceada para nação. Esta análise não se encerra numa percepção centrada em Angola, mas implica perceber a presença de Portugal e do Brasil nas narrativas de Pepetela, como contrapontos (próximos e distantes), presentes neste processo de efetivação da "nação imaginada".

Palavras-Chave: Nação, literatura, Angola, Pepetela.

Proponho aqui uma análise sobre a produção literária do escritor angolano Pepetela, nas duas primeiras décadas após a independência do país, a partir de 1975, procurando demonstrar o papel ativo do escritor no processo de elaboração das referências simbólicas da nação, bem como seu papel político no processo de institucionalização da literatura no país. Neste caso, a história, a literatura e a política se confundem com a institucionalização da União dos Escritores Angolanos e o processo de formação do Estado independente, em meados da década de setenta. Com base na análise de Benedict Anderson (1989), sobre o que ele denominou de "comunidade imaginadas", procuro analisar como ocorreu parte do processo de simbolização coletivo sobre a idéia de nação em Angola.

* Doutor em Antropologia. Professor Ajunto na Universidade Federal de Sergipe. 
Apesar de não tratar especificamente do contexto anterior à independência, momento que foi de intensa produção literária em meio a guerra anti-colonial, que ocorreu entre 1961 e 1975, é importante registrar que tal produção foi um dos fenômenos mais interessantes do processo político de contestação do colonialismo português e esteve ao lado da militância pela independência. Vários pesquisadores já se debruçaram sobre este tema ${ }^{1}$, que, sem dúvida nenhuma, evidencia a relação entre a produção literária e os movimentos políticos de contestação e está diretamente relacionado com o que tratarei neste artigo. No entanto, gostaria de propor pensar aqui a relação entre a produção e a veiculação de literatura no contexto de uma Angola independente. Primeiro, pelo enfoque que darei ao volume representativo desta produção; segundo, pela caracterização que farei sobre a forma e o conteúdo dos romances de um dos escritores mais ativos e representativos do país em tal contexto.

\section{Pepetela e a produção literária em Angola}

O que havia para ser lido em Angola, nas duas décadas seguintes à independência, eram os livros dos escritores associados à União dos Escritores Angolanos (UEA), entre eles: Agostinho Neto, Arnaldo Santos, Boaventura Cardoso, Henrique Abranches, José Luandino Vieira, Manuel Rui, Uanhenga Xitu, Rui Duarte de Carvalho, Pepetela e outros. Todos membros do Movimento Popular de Libertação de Angola (MPLA) ou simpatizantes, e todos publicados pela UEA após a independência. No caso de Pepetela, seus livros foram, à época, a prosa em romance mais presente em números de títulos e em volume de exemplares publicados em Angola. A partir de 1977, até o fim dos anos oitenta, Pepetela publicou seis romances: As aventuras de Ngunga [1973], Muana Puó [1978/79], Mayombe [1980], Yaka [1984], O cão e os caluandas [1985] e Lueji [1989], e duas peças de teatro, A corda [1978] e A revolta da casa dos ídolos $[1980]^{2}$. Nenhum outro escritor publicou, no mesmo período, tanto quanto Pepetela no que diz respeito à prosa e, em especial, ao romance.

A União dos Escritores Angolanos foi uma das primeiras instituições criadas em Angola, um mês após a proclamação da independência, no dia 10 de dezembro de 1975, data dada como comemorativa do vigésimo ano da fundação do MPLA, quando se reuniram 32 escritores para sua fundação. $\mathrm{O}$ ato de criação da UEA foi presidido pelo escritor e então presidente da República, Agostinho Neto. A instituição foi criada com a finalidade de reunir os escritores angolanos, estimular a criação literária e, nos dizeres de Agostinho Neto, promover a "cultura nacional". 
Segundo Pepetela, em entrevista concedida em 2003, sobre a UEA e a participação dele próprio e outros na instituição:

Em 1975, houve um grupo, acho que começou com o Luandino Vieira, o Manuel Rui Monteiro e Costa Andrade. Foram os três que começaram a discutir a idéia de criar a União. Isto ainda antes da independência. Depois deste grupo, o Arnaldo Santos e eu junto com os três escrevemos a proclamação da "União", que foi proclamada no dia 10 de dezembro de 1975. Depois, mais tarde, nós os cinco formamos a comissão de instalação e dirigimos os destinos da organização por alguns meses até haver uma direção, já eleita. E fui eu a dar posse ao presidente Agostinho Neto como presidente da Assembléia Geral da União. Quer dizer eu lhe disse "tome posse", e quem era eu para lhe dar posse, e ele "tomou posse" (risos). E, desde então, colaborei muitas vezes, estive na direção, e em alguns momentos que estive no governo não poderia lá estar, mas depois que saí do governo estive muito tempo nas relações exteriores da União, depois fui presidente da direção, durante dois ou três mandatos e depois mais tarde fui presidente da Assembléia Geral e pronto, depois saí já há um ano e tal, para os mais novos ocuparem. ${ }^{4}$

Pepetela teve toda uma intimidade com a UEA desde a criação e do auge da produção literária dos escritores da instituição até anos atrás em que exerceu o cargo de presidente da Assembléia Geral da "União".

Na primeira década a partir da independência, a literatura angolana foi adotada nos currículos escolares e passaram a ser criadas antologias que eram estudadas nos diferentes módulos educacionais, o que demonstra a relação da produção literária da UEA com a leitura de alfabetização. ${ }^{5}$ Além das antologias que circulavam nas escolas, alguns títulos chegaram mesmo a ser aconselhados para leitura e estudos. ${ }^{6}$ Outros materiais publicados, que passaram a ser utilizados logo depois da independência, foram o Manual de alfabetização e o livro História de Angola, que foram produzidos pelo Centro de Estudos Angolanos, na década de sessenta, na Argélia, e do qual Pepetela fez parte.

Apesar da infinidade de línguas étnicas em uso oral em Angola ${ }^{7}$ a língua escrita corrente e da alfabetização foi a língua portuguesa. Para Appiah (1997), em toda a África ocorreu a imposição cultural dos valores civilizacionistas impostos pelas pedagogias dos impérios coloniais, a começar pela língua. Citando Roland Barthes, Appiah (1997) continua seu argumento para dizer que, para além do meio (a língua) pelo qual se ensina, a literatura é "o quê" se ensina. Isto serve para pensarmos que com a institucionalização do 
Estado nacional angolano (mais a criação da UEA e a produção e difusão literária ligada ao sistema educacional) a literatura começou a ter uma estreita relação com o que se passou a dizer sobre a "nação" em Angola. Manifestações literárias que enfatizavam um "nós" local, como "nossos problemas" e "nossas realidades", como também uma narrativa sobre a forma do que caracteriza a "nossa literatura", o "nosso estilo", a "nossa tradição", ou seja, a ênfase numa singularidade imaginada de pensar, dizer, sentir e expressar como propriedades determináveis daquilo que Agostinho Neto anunciava ser necessário promover como "cultura nacional", uma cultura nacional que se expressa em língua portugesa.

Do ponto de vista da produção e da circulação dos livros, até o final dos anos oitenta, todas as publicações em Angola foram realizadas pela União dos Escritores Angolanos ou pelo Instituto Nacional do Livro e do Disco (INALD) que negociavam a publicação com as editoras do exterior. A produção e a impressão dos livros que circulavam em Angola eram realizadas por editoras portuguesas contratadas pela UEA, o que envolvia alguns acordos de publicação para as edições que saíssem em Portugal. No fundo, do ponto de vista editorial, o que se modificava era o selo, que em Portugal circulava com o selo da editora portuguesa e em Angola com o selo da UEA ou do INALD. No caso específico da obra de Pepetela, isto se repetiu até o momento da publicação de Yaka [1984], quando já não houve mais acordo entre a Edições 70 e o escritor (editora que foi a principal parceira portuguesa da UEA nos primeiros dez anos de sua existência). Através das Edições 70 foram publicados em Portugal, entre 1975 e 1989, sessenta e dois títulos de escritores angolanos, entre prosa e poesia. ${ }^{8}$ Período que também corresponde ao auge da publicação de livros pela UEA, em Angola. Pepetela foi além destas relações e articulou com a Editora Ática no Brasil a publicação em primeira mão do seu romance Yaka [1984], na coleção denominada "Autores Africanos", mantida nos anos oitenta e que já havia publicado outros títulos de Pepetela, como As Aventuras de Ngunga e Mayombe, além de outros escritores angolanos.

Isto significa que ao mesmo tempo que a literatura destes escritores era difundida internamente, era também difundida para o exterior e os países de língua portuguesa se tornavam os principais espaços de circulação, mesmo que restrita, destes livros entre pequenos grupos. Uma narrativa que foi tornando o registro de como os atores do universo literário, às vezes também político em Angola, principalmente ligados ao governo do MPLA, percebiam o país, em termos de história, política, cultura e sociedade. Perspectivas que passaram a fazer parte de um imaginário coletivo que se 
produzia sobre Angola através da literatura, afetando tanto uma audiência externa quanto interna.

Sobre as publicações da UEA e a importância quantitativa representativa desta produção em Angola, Pepetela enfatiza que:

[...] num longo período que vai de 1977, que é quando começou a publicar a União, até 1989/90, acho que foi um bom período da União dos Escritores como editora, fazia-se assim qualquer coisa como talvez uns vinte livros por ano. Não era mais do que isto. Eu lembro que em 1988/89 nós contamos trezentos livros, desde 1977 a 1989. Provavelmente haja, agora [2003], trezentos e vinte livros publicados, quer dizer que depois disto houve muito pouco livro publicado. [...] Eram tiragens muito fortes. Normalmente um livro de poesias ia à primeira edição para 5.000 a 10.000 exemplares. Dependia se já era um poeta mais conhecido ou menos conhecido. Prosa, era normalmente 10.000 exemplares e para alguns autores 20.000 exemplares na primeira edição. Depois na segunda edição ia para 20.000 exemplares. Como eu disse ontem, o preço do livro era muito barato e o Estado subsidiava os livros. [...] 20.000 exemplares era o número sempre de minhas primeiras edições. Sempre a partir daí. Desde As aventuras de Ngunga, Mayombe, foi sempre 20.000 exemplares. Talvez não Muana Puó, que foi o segundo livro e deve ter tido uma edição mais pequena, de 10.000 exemplares. Ele era um livro muito difícil, as pessoas não entendiam, e nunca mais teve re-edições aqui, teve re-edições em Portugal, mas aqui não. Mas depois disto, de Mayombe, Yaka, sempre 20.000.

Esta situação configura dois momentos distintos na difusão da literatura dos escritores angolanos em geral e da literatura escrita por Pepetela. Um momento a partir da independência do país, juntamente com a criação da UEA, em que o pesado subsídio do Estado angolano à publicação corresponde à época de compromissos com um formato de governo que se propunha socialista e popular; e um outro momento de ruptura e queda nesta produção, em que, acompanhando mudanças na ordem mundial, também o governo angolano começa a promover transformações políticas profundas para inserir-se no novo contexto econômico de mercado globalizado que se impôs com a derrocada da União Soviética.

Pepetela foi Vice-Ministro da Educação, além de membro atuante e fundador da União dos Escritores Angolanos. Naquele momento, projetos e políticas culturais voltadas para a consolidação do Estado nacional foram adotados no país pelo governo de partido único do MPLA. Foram projetos 
que envolveram a ação no campo da institucionalização e difusão do uso da língua portuguesa, através da alfabetização e do ensino escolar, bem como o incentivo e subsídio à produção literária, à música, ao teatro, ao cinema e às artes plásticas em geral. Pepetela deixou o ministério em 1982, logo depois de comandar a reforma universitária no país, e continuou publicando pela UEA até o final dos anos oitenta, quando saiu Lueji, em 1989, seu último livro publicado com a chancela da "União". Diz ele:

O Lueji ainda saiu em um bom tempo. Teve uma primeira edição muito grande. Teve seus 20.000 exemplares, o habitual. Mas em seguida é que entra ou começa a entrar a nova economia. O Lueji foi publicado em 1989 e em 1990 entra a nova economia. E a partir daí novas edições já não há. Os preços dos livros foram multiplicados por cem. Então, aí já uma segunda edição só saiu bem mais tarde em Portugal. E, aliás, por ser grande [são 486 páginas] era mais difícil publicar em Portugal, também. Mas com a edição angolana estava paga a edição portuguesa. ${ }^{9}$

A referência ao romance Lueji marca um ponto de virada na política de investimento cultural do governo angolano (neste caso específico interessa aqui o investimento sobre a literatura, apesar de terem sido afetadas também a produção musical e de artes plásticas, por exemplo). Progressivente os escritores tiveram de recorrer à iniciativa individual e ao financiamento privado para seus livros, assim como perderam audiências pelo encarecimento do livro em Angola, bem como pela redução das tiragens.

A partir de 1992, ou seja, do romance A geração da utopia [1992] em diante, os livros de Pepetela não foram mais publicados em Angola, até os últimos dez anos, quando começaram a surgir editoras privadas no país, revitalizando a produção e publicação de livros em geral, num outro contexto político e econômico. ${ }^{10}$ Por exemplo, um acordo de Pepetela com a Editorial Nzila ${ }^{11}$, estabelecida em Luanda no final dos anos noventa, previa a publicação de todos os títulos do escritor que ainda não tivessem sido publicados no país, seguindo a seqüência cronológica dos publicados em Portugal durante a década de noventa. ${ }^{12}$ Podemos considerar os anos noventa como um período de abrandamento severo das publicações em geral no país, pela retirada de incentivos do Estado tanto na publicação quanto na distribuição de livros, o que provocou um encarecimento exorbitante do produto e tornou o acesso altamente restritivo.

Com o fim dos subsídios estatais, a edição e a difusão das obras em Angola foram reduzidas drasticamente, e aqueles autores que já tinham reconhecimento internacional saíram em busca de oportunidades para novas 
publicações de seus livros. Durante os anos noventa a publicação em língua portuguesa de livros de escritores angolanos foi negociada diretamente pelos autores ou seus agentes com editoras comerciais portuguesas e em alguns casos brasileiras. Por exemplo, os títulos escritos e publicados por Pepetela durante a década de noventa chegavam a Angola por importação de uma parte dos exemplares editados em Portugal ou Brasil, com preços altos e menores números de exemplares.

\section{A NAÇÃO IMAGINADA NOS ROMANCES}

Uma das qualidades literárias de Pepetela, ressaltada pela crítica internacional durante os anos oitenta e noventa, é a versatilidade dos formatos narrativos construídos pelo escritor em seus romances. Numa entrevista concedida a um jornal português, em novembro de $1990^{13}$, Pepetela é questionado sobre a presença dos diferentes narradores em seus livros. Sobre como ele desenvolveu esta habilidade de transitar entre o ponto de vista do autor, dos narradores e dos personagens, ele responde que é uma prática que vem do seu conhecimento da "tradição oral", de ter lido e ouvido muitas vezes os "contos tradicionais", pois "essa facilidade de passar da pele do narrador para o discurso de cada um dos personagens é uma constante nos hábitos da narração oral angolana”. Além disto, ele justifica que esta é uma prática intencionalmente trabalhada em seus romances. Em tal modalidade narrativa, "quando está alguém a contar é fácil entenderem-se as passagens: há a presença do gesto, há a riquíssima mímica do contador de histórias...". É desta modalidade da experiência apurada com as narrativas da "tradição oral" que Pepetela diz ter desenvolvido tecnicamente seus jogos de linguagem para contar histórias escrevendo romances.

Tal versatilidade narrativa foi utilizada muito articuladamente com experiência de Pepetela como historiador e cientista social. Sobre Yaka [1984], por exemplo, Pepetela diz que fez pesquisas para escrevê-lo e que em sua narrativa procurou ser o mais próximo possível da "história" ${ }^{14}$, indo a documentos e livros portugueses e estrangeiros disponíveis na época, todos dos tempos coloniais, numa tentativa de reinterpretá-los "do ponto de vista de uma perspectiva nacional". ${ }^{15}$ Conta ele:

Fiz a pesquisa sobre a história e procurei ser o mais próximo possível da história. Aliás, demasiado próximo. Foi a única vez que eu estive muito próximo da história mesmo. Documentos, livros que havia, todos coloniais, praticamente portugueses, ou estrangeiros ligados ao colonial. Aí, então, 
a tentar re-interpretar, uma coisa que fui apreendendo desde a Argélia, a re-interpretar a história a partir dos textos de relatos coloniais. Importante tentar descrever uma história nacional. O Yaka é do ponto de vista de uma perspectiva nacional, apesar de estar a contar a história de uma família colonialista. Para isto tive estudar bastante a documentação que existia na época ou eu tinha disponível.

Se sobre Yaka [1984] Pepetela diz reconhecer que esteve ainda assim muito próximo da "história" - de nomes, fatos e contextos - foi com sua escrita, ao fim dela, que ele diz ter aprendido a ficar mais à vontade com relação à "história" e "tranqüilo para criar"16, no sentido de escapar às noções de "factualidade" e de "veracidade" vinculadas aos documentos como que efeitos de um "mundo real", capaz de ser evidenciado e reproduzido pela escrita.

Talvez a personagem Lu, de Lueji [1989], signifique, anos mais tarde à publicação de Yaka, o papel da própria autocrítica para Pepetela. A personagem, que também é uma narradora fictícia, está escrevendo o roteiro para uma performance de balé sobre o poderoso reino da Lunda e pede auxílio a várias pessoas e, dentre elas, Herculano, um personagem do romance que é caracterizado como historiador. Herculano diz que o roteiro que ela havia escrito era um absurdo do ponto de vista da "verdade", pois "não se pode brincar assim com a História". ${ }^{17} \mathrm{Na}$ discussão, Herculano teoriza sobre a questão da "tradição oral" e suas versões contraditórias, dizendo que a versão "tradicional" é sempre ideológica. Ele argumenta que para chegar a uma "versão científica" é necessário se comparar todas as versões contraditórias ou não e ver o que há de comum nelas. ${ }^{18}$ Enquanto Herculano enfatiza que a "verdade deve estar no meio"19 das diferentes versões, como uma síntese, Lu defende o seu roteiro e responde que toda narrativa sobre a história de Lueji e o nascimento de um império lunda é uma outra interpretação das várias versões narrativas existentes, sejam as orais ou escritas.

Lu diz que qualquer versão "histórica”, pretensamente científica, seria uma "versão ideológica" como qualquer outra. E, continua:

O que realmente se passou naqueles tempos tão antigos, é mentira, ninguém vai saber. Por muitas metodologias científicas que se usem. O que importa é o que as pessoas imaginaram, criaram, a partir dos factos definitivamente enterrados na areia. Nos interessa a imaginação, a poesia, a mensagem que os intelectuais da época sintetizaram no mito. E esse mito por isso pode ser mudado à vontade, é a liberdade da imaginação, da criação artística. E abaixo a tirania dos dogmas. Sobretudo os pretensamente históricos. Tu, Herculano, 
dizes não é lógico que fizessem assim ou assado. Não é lógico dentro da tua lógica de hoje. Que sabes tu sobre a lógica daquela época? ${ }^{20}$

Na continuação do diálogo entre os dois é questionada a noção de "história" e de "mito". O narrador reconhece os diferentes discursos sobre tais conceitos e as implicações de poder em que se encontram. O próprio romance Lueji [1989] também é uma história imaginada e criada a partir de outras narrativas advindas da oralidade ou da escrita. Talvez Pepetela, assim como Lu, ao polemizar a questão, pretenda desestabilizar a postura do historiador Herculano sobre "ficção" e "verdade", ou mesmo a sua própria postura. Ao reconhecer e problematizar tais argumentos não significa que Pepetela estabeleça qualquer entendimento de hierarquização de valores de uma modalidade narrativa sobre a outra, seja o "mito", o "romance" ou a "historiografia", mas contribui para entendermos a opção do autor pelo romance como um "campo de expressão" privilegiado para falar da "nação" como que constituída num dado "processo histórico", tributária de uma ancestralidade específica.

Em A gloriosa família [1997], o tema também está relacionado ao passado. O principal narrador do romance é um escravo mudo que observa o dia-a-dia da vida da família de Baltazar Van-Dunem em Luanda, durante a ocupação holandesa, no século XVII. A opção pelo romance para falar deste tema, como de outros, é um exercício crítico de liberdade e aprendizado sobre a nação e sobre o que Pepetela considera o passado desta. A "temática histórica" torna-se uma estratégia de leitura a contrapelo de outros textos canônicos, principalmente os textos coloniais, que são a grande maioria das fontes históricas escritas disponíveis sobre Angola. Pepetela afirma que seus romances são sempre atualizados por preocupações ligadas ao momento do presente em que foram escritos ${ }^{21}$, mesmo quando se tratando de temas do passado. São as leituras de Pepetela sobre narrativas orais, livros e documentos que despertam o seu desejo pela escrita em uma outra forma narrativa, o romance, em que a nação pode ser imaginada como contraponto aos registros das escritas coloniais.

Se, por um lado, a narrativa mais antiga de que se tem conhecimento sobre os acontecimentos dos tempos da ocupação holandesa de Luanda e de Benguela é o livro escrito por Oliveira Cadórnega (1972), um português que viveu em Luanda no século dezessete, Pepetela, por outro lado, subverte o formato colonial daquela narrativa e a imagina recriada na voz de um escravo nascido no reino da rainha Jinga. O romance se torna uma versão que desarranja a narrativa histórica e documental, 
subvertendo a autoridade colonial do texto de Cadórnega, imaginando o que poderiam ter pensando, dito ou visto, outras pessoas daquele tempo, principalmente aquelas que não dominavam a escrita, como o escravo narrador no romance.

Quando Pepetela convoca Cadórnega ou quando utiliza outras fontes e bibliografias portuguesas dos tempos coloniais, como os expedicionários Henrique de Carvalho, Capello e Ivens e Serpa Pinto, em romances como Yaka [1984] e Lueji [1989], é para minar a perspectiva colonial do passado, contraponto-a com uma perspectiva que ele considera como sendo angolana. ${ }^{22}$ Tais características são claramente parte de seu projeto literário até fins dos anos noventa.

É importante registrar que desde os tempos coloniais o "poder da escrita" em Angola é muito representativo politicamente. A pesquisadora Inocência Mata (2003) diz que alguns amigos seus, em Angola, chegam a considerar o romance Yaka [1984], por exemplo, como interpretação da "história", até mesmo como uma "narrativa histórica". A publicação literária dos primeiros quinze anos após a independência, em Angola, carrega esta autoridade, porque, segundo Mata (2003), foi a forma de expressão escrita em livros e a modalidade de interpretação mais significativa produzida nos primeiros anos da consituição do país. É a modalidade de registro escrito e narrativo mais contundente em termos de produção de memória sobre a nação. No caso específico de Pepetela, isto é mais legítimo pelo fato de o escritor marcar a sua narrativa com "sinais reconhecíveis de historicidade", diz Mata (2003), por incluir fatos ou personagens lendários, míticos ou históricos em seus romances. A narrativa ganha, assim, estatuto legítimo por ser um texto que verbaliza e sistematiza algo reconhecível pelos leitores, ao mesmo tempo em que está imbuído de uma certa autoridade para narrar a nação em virtude da trajetória biográfica do escritor.

Em Yaka [1984], apesar de um exercício "próximo demais da história", como diz Pepetela na entrevista citada acima, ainda assim, o escritor intervém como o autor-narrador, em "Nota prévia", para enunciar didaticamente o que irá contar a seguir, através de outros narradores fictícios.

Nota prévia

Yaka, Mbayaka, jaga, imbangala?

Foram uma mesma formação social (?), Nação (?) - aos antropólogos de esclarecer. Certo é que agitaram a já tremeluzente História de Angola, com as suas incursões ao Reino do Congo, na última das 
quais cercaram o rei numa ilha do grande rio e iam lhe cortar a cabeça, quando os portugueses intervieram para salvar a coroada cabeça, ainda não vassala. Foi o princípio do que se sabe. Na Matamba, deram força à legendária Rainha Njinga (ou Nzinga), que empurrou o exército português até no mar. Talvez Njinga fosse yaka? A hipótese ainda não morreu. Os ditos guerreiros, que por comodidade chamo de yaka, desceram para o sul e já no Centro ocidental de Angola aprisionaram o inglês Battel que deles conta coisas de estarrecer - ingratidão do inglês, pois até o deixaram vivo para poder contar a estória. Tiveram influência certa no dito Reino de Benguela, formaram chefias nas terras dos Muila, Gambo, já lá bem no Sul, irrequietamente voltaram a subir, formaram chefias no Planalto Central, em Caconda, Huambo, Bailundo, Bié. . .

E o círculo yaka ficou fechado nesses séculos antigos. Criadores de chefias, assimiladores de culturas, formadores de exércitos com jovens de outras populações que iam integrando na sua caminhada, parecem apenas uma idéia errante, cazumbi antecipado da nacionalidade.

Mas não é deles que trata este livro, só duma estátua.

E a estátua é pura ficção. Sendo a estatuária yaka riquíssima ela poderia ter existido. Mas não. Por acaso. Daí a necessidade de a criar, como mito recriado. Até porque só os mitos têm realidade. E como nos mitos, os mitos criam a si próprios, falando.

O Autor ${ }^{23}$

É a história da nação em questão. Pepetela começa o romance questionando a existência de uma formação social yaka, talvez "mbayaka, jaga ou imbangala". Um cazumbi ou espírito "antecipado da nacionalidade". Uma formação social de "assimiladores" de diferentes culturas, tanto que suas narrativas se confundem com as de outras populações do Sul, Centro e Norte de Angola. Como se um projeto de convergência cultural da nação já estivesse em curso antes mesmo do colonialismo português.

Yaka é um símbolo emblemático e representativo de outros muitos mitos tradicionais, talvez na perspectiva de um "mito" que o escritor queira ver recriado como "mito" da nação. "Os mitos criam-se a si próprios, falando", diz o narrador-autor. Em certo sentido, o romance Yaka [1984] está abordando outras questões para além de qualquer "formação social" yaka, questões que envolvem a "história" de uma Angola de referências "tradicionais", do colonialismo, das guerras e da independência.

No que diz respeito à temática do período colonial e da independência, além de tratar Portugal como antítese ao projeto nacional 
angolano, de um elo que se deve romper para se contruir o novo, aparece reiteradamente o Brasil, referenciado em Yaka, A gloriosa família [1997] e A Geração da Utopia [1992], imaginado como contraponto e como símbolo positivo de uma interlocução histórica de convergências políticas, econômicas e culturais em diferentes momentos do que seria o passado angolano. Pepetela evidencia o trânsito de escravos, de comerciantes, de famílias, de produtos, de artefatos, de idéias e de práticas entre os dois lados do Atlântico. Além disto, nos três romances, aparecem menções que ressaltam uma relação de proximidade e de admiração sobre a autonomia política e cultural do Brasil, como um espelho possível de nação para Angola.

A expressão literária brasileira aparece como modelo de um pensamento e uma produção cultural autônomos, exemplificado através do Movimento Modernista e, a partir dele, evidenciado em $A$ geração da utopia [1992], como uma manifestação estética e política de ruptura do Brasil com Portugal. O fluxo e o interesse mútuo entre brasileiros e angolanos durante o período escravocrata é tratado em $A$ gloriosa família [1997], tanto para ressaltar que as frotas que libertaram Luanda e Benguela do domínio colonial holandês no século dezessete foram organizadas no Brasil, mas também para destacar que o modelo de organização social em Luanda era algo próximo de cidades brasileiras como o Rio de Janeiro e Salvador. Além disto, a influência da experiência de autonomia, com a independência política do Brasil, no século dezenove, aparece no romance Yaka [1984] como que provocando sentimentos políticos de solidariedade nos angolanos de Benguela, não só por insuflar politicamente ideais de autonomia, mas pelas relações familiares e interesses econômicos mútuos, que o escritor diz terem existido entre grupos sociais dos dois lados do Atlântico.

Vale ressaltar que os três romances mencionados acima foram publicados no Brasil há mais de dez anos, bem como que o escritor já mencionou em diferentes entrevistas sobre sua trajetória, que foi e é leitor de vários autores brasileiros, como: Jorge Amado, Guimarães Rosa, João Ubaldo Ribeiro, entre outros. Pepetela reiteradamente fala que acompanhou uma forte interlocução que existiu entre os escritores brasileiros e angolanos desde os primeiros anos que antecederam a guerra colonial, na década de sessenta. O Brasil parece aí se tornar uma referência simbólica de alteridade constituinte do passado da nação angolana ${ }^{24}$, não uma alteridade antagônica, mas antes uma referência de proximidade fraterna. 
Em Yaka [1984] e como sucede em Lueji [1989], A geração da utopia [1992] ou A gloriosa família [1997], o romance de Pepetela é este lugar de encontro de muitos discursos, seja qual for o formato narrativo em que ele apareça. Em geral, a modalidade narrativa do romance carrega esta ambigüidade sobre a noção de que não existe "fato histórico" ou "verdade histórica" a não ser no discurso, porque nele a narrativa se afasta do "discurso da história" e por outro lado também se estabelece no próprio campo do discurso sobre algo, neste caso a nação. Os romances são marcados pela temporalidade em seu percurso narrativo, bem como pela escrita e pela indisciplina do pensamento, a príncípio por certa liberdade imaginativa, estética e política no tratamento dos temas. É neste "campo de expressão" que Pepetela sente-se descomprometido com as chamadas "teorias sociais" (apesar da presença delas nos diálogos entre seus personagens) e se diz "tranqüilo para criar", talvez no sentido de imaginar a nação e por isto um passado recriado para um novo país.

No romance $A$ geração da utopia [1992], o personagem Aníbal, nascido em Luanda, vive em Portugal, no ano de 1961, e é formado no curso de "Histórico-Filosóficas". Ele conta aos amigos da Casa dos Estudantes do Império, em Lisboa, que o Mário de Andrade e o Viriato da Cruz estão à frente das primeiras ações revolucionárias pela independência em Angola. "Dizem que foram eles que organizaram os ataques às prisões em Luanda. Chama-se Movimento Popular de Angola, MPLA"25. Neste caso, Aníbal faz referência ao "04 de Fevereiro de 1961", data da investida popular às prisões em Luanda, exigindo liberdade aos presos políticos anticolonialistas. É importante salientar que o "04 de Fevereiro" foi transformado em data cívica emblemática para a Angola da luta anticolonial e de após a independência, por ser considerado um marco do início da luta pela libertação do país. O evento foi apropriado pelo MPLA e transformado numa data de afirmação do primeiro movimento revolucionário de massa articulado pelo partido e propagado como marco deflagrador da guerra anticolonial. No entanto, embora o MPLA tenha requisitado a responsabilidade e orientação do levante, sua liderança foi questionada por opositores políticos e por estudiosos do assunto. Até hoje, existem dúvidas quanto à autoria da articulação de tais ações. Em $A$ geração da utopia [1992], a fala de Aníbal reforça a autoria do MPLA e a participação de Viriato da Cruz e Mário Pinto de Andrade no levante, mesmo reconhecendo que eles estavam fora de Angola naquele momento. Independente das contradições existentes sobre tais responsabilidades, Aní- 
bal atribui a participação dos dois na articulação do levante do dia "04 de Fevereiro de 1961". O personagem Aníbal é um jovem engajado nos ideais de independência de Angola e se filia ao MPLA, articulando sua saída de Portugal e o seu encontro com alguns membros do movimento exilados na França, e de lá seguindo para a guerrilha no interior de Angola, ${ }^{26}$ algo que se confunde com o próprio percurso biográfico de Pepetela.

Também em Yaka [1984], a referência aos "acontecimentos" do ano de 1961 é feita no capítulo "O Sexo (1961)", em que a perspectiva da narrativa sobre Benguela e a família Semedo põe em evidência o início da guerra anticolonial. Neste caso, a ênfase é sobre como as notícias dos primeiros levantes ocorridos no "Norte" e em Luanda afetaram a estrutura colonial em outras partes de Angola, principalmente em Benguela. Os "acontecimentos" de 1961 são narrados em Yaka [1984] como referências ao nascimento de uma conscientização nacional dos vários embates regionais movidos por múltiplos interesses, mas tendo em comum a luta pela descolonização.

Nos dois romances, é Pepetela a "fazer" e pensar sobre um passado recente da nação, ainda que anterior à institucionalização do próprio Estado nacional, mas que ainda está presente na memória de muitas pessoas que vivenciaram aqueles acontecimentos, inclusive na dele. De qualquer forma, o registro de datas, de fatos, de nomes, de lugares, de conflitos é sistematizado pela narrativa dos romances, antes mesmo de existirem trabalhos historiográficos amplamente publicados sobre os assuntos.

Em Yaka [1984], A geração da utopia [1992] e A gloriosa família [1997] há uma ênfase de núcleo temático à gênese duma nação angolana projetada num passado cronológico. Os títulos dos capítulos são organizados de maneira linear, ressaltando continuidades e temporalidades da própria organização política da nação, bem como certa factualidade marcada por momentos de tensão ou momentos cíclicos de abertura e fechamento de dadas conjunturas políticas e sociais imaginadas pelo escritor.

Nos capítulos "A Boca (1890/1904)", "Os Olhos (1917)", “O Coração (1940/41)", “O Sexo (1961)" e "As Pernas (1975)”, no romance Yaka [1984], a linearidade cronológica da narrativa situa a vida do protagonista Alexandre Semedo num "tempo da nação" anterior à independência. É o tempo colonial da nação. As datas nos capítulos se referem as sucessivas guerras que ocorreram no Sul de Angola desde o chamado ultimatum inglês, após a Conferência de Berlim, e que estabeleceu a partilha da África pelo imperialismo europeu, passando pelas chamadas guerras coloniais de pacificação, até a guerra pela independência, finalmente concretizada em 1975. ${ }^{27}$ A cronologia dos acontecimentos da vida de Alexandre Semedo é análoga à cronologia do tempo colonial da nação. 
Em A geração da utopia [1992], os capítulos “A Casa (1961)”, “A Chana (1975)", "O Polvo (Abril de 1982)" e "O Templo (a partir de Julho de 1991)" marcam uma cronologia da nação que se inicia em 1961, ano do começo da guerra contra o colonialismo em Angola. No segundo capítulo, 1975 é ainda um ano de guerra no romance, mas remete principalmente à memória da independência do país, efetivada em 11 de novembro de 1975. O ano de 1982 é de transformações e desilusões, mais propriamente na relação de Pepetela com o Governo, é o ano em que ele se afasta de suas atividades políticas, deixando o Vice-Ministério da Educação. O ano de 1991 é o ano em que Pepetela escreve $A$ geração da utopia [1992], assistindo a um momento de transformações no país, em que os primeiros reflexos das profundas reformas institucionais e administrativas desmantelaram o socialismo de Estado, promovendo abertura do país ao livre mercado.

A gloriosa família [1997] constitui-se de doze capítulos, também com subtítulos indicando linearmente datas entre o "Capítulo Primeiro (Fevereiro de 1642)" e "Capítulo Décimo Segundo (Agosto de 1648)" que se referem ao período de sete anos da invasão holandesa a Luanda e Benguela. Um tempo da Angola colonial, que assim como um outro texto de Pepetela, o do drama A revolta da casa dos ídolos [1980], sobre o ano de 1514, no "Reino do Kongo", também marca a idéia de remota ancestralidade da nação. A "revolta da casa dos ídolos" é uma referência ao que teria sido uma das primeiras manifestações da resistência da população local contra o colonialismo português e contra as missões da Igreja Católica que o acompanhavam. Em A Gloriosa Família [1997] é a contestação dos colonialismos que passaram por Luanda, como o português, o holandês e mesmo o brasílico ${ }^{28}$, aqui também em questão.

\section{Considerações Finals}

Para Benedict Anderson (1989), as comunidades nacionais passam a ser imaginadas a partir do momento em que passam a ser comunicadas numa língua e numa linguagem específicas. O uso e o controle dos mecanismos de produção e difusão impressos permitem um outro avanço e uma certa hegemonia e proeminência das idéias daqueles que têm acesso aos meios de reprodução mecânica da linguagem. Por mais que não haja uma imposição de valores, há uma projeção de idéias que são dirigidas a um amplo espaço territorial e político, bem como tais idéias são difundidas, instituindo uma certa ordem do dia por onde os impressos circulam e são lidos.

Como vimos, mitos, tradições e fatos históricos integram os romances de Pepetela sobre a nação porque os circunscreve a um espaço político es- 
pecífico. Estes referenciais simbólicos são transformados "na temporalidade arcaica, atávica, do Tradicionalismo", como diz Homi Bhabha (1998, p. 211), convertendo o território em um e as populações num único "povo": o nacional. Pepetela faz significar a nação investido-a de um a priori temporal e espacial, bem como construindo-a como performance narrativa. (BHABHA, 1998). São formas de argumentar através do registro simbólico sobre o que é o passado, a população e o território do país, inscrevendo a nação.

Os romances de Pepetela estão sempre fazendo um retorno alegórico à nação, embora seja importante ressaltar que o escritor não vê a nação como algo pronto e acabado e muito menos desprovida de conflitos internos (ao menos é que o demonstra sua atividade literária até hoje, sempre crítica e revisionista), assim como sua postura política ao abandonar o envolvimento com o governo. Nos livros que analisei esteve em questão o passado (do mito, da tradição ou da história) como um tempo narrado em que se articula uma percepção sobre o que é comum à heterogeneidade populacional do país, mesmo que sob tensão social. $\mathrm{O}$ argumento fundador da nação é a retórica do convívio coletivo, mesmo que marcado pelo sofrimento e pelas contradições. Neste sentido, a nação é imaginada nos romances a partir de narrativas sobre um "processo de origem", sistematizado por uma idéia de continuidade e processos singulares. Ao escrever insistemente e reiteradamente sobre a nação, Pepetela constitui a própria imaginação sobre ela.

Nas últimas décadas do colonialismo, a principal característica das literaturas nacionalistas foi ressaltar a sua própria diferença em relação à metrópole, propondo falar das coisas da África, não envoltas pelo exotismo e sim idealizando uma perspectiva nativista de valorização humana e dos costumes locais, requisitando também sua singularidade literária. No caso de Angola, isto irá se refletir nas temáticas, mas também em um modo de narrar que evoca o vocabulário e as linguagens locais, bem como a referência aos costumes e a um jeito de falar a partir de "dentro" da nação, e que pretendia marcar suas fronteiras com a perspectiva colonial. Este é um projeto que Pepetela segue a risca nos romances aqui analisados. Além disto, não há como ler seus romances sem pensarmos na História de um País. Ele propositalmente nos confunde entre estes dois campos de expressão ao mencionar personagens e fatos políticos conhecidos, advindos principalmente dos registros coloniais.

A ausência de uma historiografia contundente produzida por angolanos e a presença de uma literatura fortemente instituída com UEA foi dando lugar a sistematização de narrativas sobre a nação no decorrer das primeiras décadas após a independência, que insistiam na idéia de que era 
necessário evidenciar um modo de "ser" e "estar" distintos da antiga metrópole. Criar alguma convergência sobre a idéia de cultura nacional, como queria Agostinho Neto, passava também pelas escolhas e pela imaginação de alguns intelectuais (e que eram ao mesmo tempo políticos), que estiveram principalmete ligados a literatura e ao MPLA.

Após a retirada dos subsídios do governo à produção literária, durante a década de noventa, a literatura produzida pela UEA já havia ganhado estatuto de símbolo nacional. Não só as publicações e os conteúdos em poesia ou prosa tornaram-se registros reconhecidos simbolicamente como nacionais, mas também seus escritores e a própria instituição literária já haviam se tornado símbolos da nação e cânone da autoridade e legitimidade do dizer e do escrever sobre Angola.

\section{The Novels of Pepetela And Imagination of the Nation in Angola}

Авsтract: In this article, I discuss the relationship between the writer Pepetela, his novels and imagination of the nation in Angola. I try to demonstrate how the trajectory of the writer's life and its relationship with the "União dos Escritores Angolanos" are part of a context of institutionalization of literature in that country as well, I try to analyse the novels and its relationship with the creation of a historical narrative romanticized to nation. This analysis no are in a perception centered in Angola, but has relation with the presence of Portugal and Brazil in the narratives of Pepetela, as and criticism (near and distant), this process of operationalizing "imagined nation".

Keywords: Nation, literature, Angola-Pepetela.

NotAS

1 Só para citar alguns: Chaves (1999), Ferreira (1974), Hamilton (1984), Laranjeira (1995), entre tantos outros.

2 Sempre estarei utilizando colchetes para fazer referência aos anos de publicação da primeira edição dos livros e parenteses para referências aos livros dos quais faço as citações diretas.

3 Ver, por exemplo, entre outros, o discurso de Agostinho Neto (2003), Sobre a Cultura Nacional, realizado em 1979, por ocasião da posse do novo corpo diretivo da UEA.

4 Cf. Pepetela. Entrevista concedida a Frank Nilton Marcon. Luanda, 13-14 nov. 2003.

Frank Marcon. Os romances de Pepetela e a imaginação da nação em Angola 
5 Pepetela informa que durante os primeiros anos da independência a Educação no país foi organizada a partir do diálogo com a pedagogia de Paulo Freire.

6 Cf.: Pepetela. Entrevista concedida a Frank Nilton Marcon. Luanda, 13-14 nov. 2003.

7 Para Anderson (1989), é através da consolidação de uma língua nacional, seja ela qual for, que se narram e se pensam as nações. As narrativas sobre a nação são transformadas em livros e atingem os lugares mais recônditos do Estado nacional através do desenvolvimento tecnológico da imprensa: primeiramente com uma língua escrita e depois pela publicação e distribuição de livros. O surgimento de uma literatura em língua portuguesa em Angola, ou seja, numa língua impressa específica, é uma singularidade que contribuiu para os diferentes modos de narrar a nação, atrelados à anuência da UEA, nos primeiros quinze anos do país.

8 No Catálogo Geral de publicações da Edições 70, ano 1988/89, as várias obras de autores angolanos estão divididas entre as coleções: "Estudos: Autores Angolanos" e "Autores Angolanos". A primeira com oito títulos e a última com 31 títulos de "ficção", 15 títulos de "poesia", 1 título de "teatro", 1 título de documentos e 6 títulos como "fora da coleção". Algumas informações sobre a relação entre a Edições 70 e as publicações de autores angolanos foram fornecidas em entrevista gravada com o proprietário e diretor da Edições 70, o senhor J. Soares da Costa, realizada em Lisboa, na sede da editora, no dia 21 de julho de 2003.

9 Cf.: Perpetela. Entrevista concedida a Frank Nilton Marcon. Luanda, 13-14 nov. 2003..

10 Quando visitei Angola, em 2003, além da União dos Escritores Angolanos, as editoras existentes e recentemente criadas eram: Edições Chá de Caxinde, Editorial Nzila e a Kilombelombe. Em 2004, surgiu outra editora chamada Mayanga, dirigida por brasileiros com sede no Brasil e em Angola.

11 A editora "Nzila" está ligada à Editorial Caminho, de Lisboa, e significa "caminho", em kimbundo. Em Portugal, a editora tem experiência na publicação de livros de escritores angolanos, moçambicanos, cabo-verdianos e brasileiros. Em Angola prioriza a publicação de escritores locais, inclusive de escritores inéditos no país. Hoje, juntamente com outras editoras fazem parte do grupo Leya representando também no Brasil e em Moçambique.

12 Cf.: Pepetela. Entrevista concedida a Frank Nilton Marcon. Luanda, 13-14 nov. 2003.

13 Cf. Pepetela. "Nós procuramos a utopia”. Expresso, 17 nov. 1990, p. 85R-87R. Entrevista concedida a António Loja Neves. Pepetela em entrevista a António Loja Neves.

14 Enfatizo que utilizo "história", com aspas, quando me reporto à noção de "história" como uma modalidade de discurso. Roland Barthes (2004) desestabiliza o 
"discurso da história" apontando-o como um discurso ideológico de pretensão realista. Entre outras coisas ele diz em sua crítica que "o fato não tem mais do que sua existência lingüística” (BARTHES, 2004, p. 177). Michel Foucault (1996), em $A$ ordem do discurso, aponta para noção de que a "verdade", a "autoridade" e o "realismo" são questões de desejo e poder relacionadas ao discurso. Destaco aqui a crítica de Foucault (1996) especificamente para articulá-la ao que diz Barthes (2004) sobre o "discurso da história".

15 As aspas deste parágrafo se referem a afirmações literais feitas por Pepetela na entrevista que cito em seguida. Pepetela. Entrevista concedida a Frank Nilton Marcon. Luanda, 13-14 nov. 2003.

16 Pepetela. Entrevista concedida a Frank Nilton Marcon. Luanda, 13-14 nov. 2003.

17 Pepetela [1989], 1997, p. 375.

18 Pepetela [1989], 1997, p. 376.

19 Pepetela [1989], 1997, p. 377.

20 Pepetela [1989], 1997, p. 377.

21 Pepetela. Entrevista concedida a Frank Nilton Marcon. Luanda, 13-14 nov. 2003.

22 Inocência Mata (2003) dedica parte de sua Tese de doutorado à relação da escrita de Pepetela com as bibliografias e documentos coloniais. Todos os autores citados neste parágrafo têm alguns de seus livros arrolados na bibliografia final desta Tese.

23 Pepetela [1984], 1984, p. 6.

24 Em Marcon (2005), trago mais evidencias destas relações com o Brasil, bem como destaco outras formas como o país aparece em outros tantos romances de Pepetela. Também trato mais detidamente da trajetória biográfica do escritor e sua relação de história familiar com Brasil.

25 Pepetela [1992], 2000, p. 20.

26 O ano de 1961 é um ano de mudanças nos rumos do colonialismo português na África e particularmente em Angola. Por exemplo, é o fim do indigenato nas colônias, ver Thomaz (2002, p. 79). Também é o início da guerra anticolonial em Angola e ano da morte de Lumumba, considerado herói da luta pela independência no Congo Belga e em Angola. Lumumba é citado como herói em Yaka [1984] e A geração da utopia [1992].

27 Sobre as guerras em Angola neste mesmo período, ver o trabalho de René Pélissier (1986).

28 Segundo Luís Felipe Alencastro (2000), os brasilícos eram os filhos dos colonos portugueses nascidos no Brasil no período colonial, que em muitos casos formavam uma elite nascida na colônia e tinham interesses econômicos, envolvimento político e mesmo familiar diretamente com os entrepostos coloniais portugueses na África. 


\section{REFERÊNCIAS}

ALENCASTRO, Luiz Felipe de. O trato dos viventes: formação do Brasil no Atlântico Sul. São Paulo: Companhia das Letras, 2000.

ANDERSON, Benedict. Nação e consciência nacional. São Paulo: Ática, 1989.

APPIAH, Kwame Anthony. Na casa de meu pai: a África na filosofia da cultura. Rio de Janeiro: Contraponto, 1997.

BAKHTIN, Mikhail. Questões de literatura e de estética: a teoria da romance. São Paulo: Edunesp, 1998.

BARTHES, Roland. O rumor da língua. São Paulo: M. Fontes, 2004.

BHABHA, Homi K. O local da cultura. Belo Horizonte: Ed. da UFMG, 1998.

CADORNEGA, António de Oliveira. História geral das guerrasaAngolanas, 1680. Lisboa: Agência Geral do Ultramar, 1972. (Anotado e corrigido por José Matias Delgado). Tomos III.

CERTEAU, Michel. A escrita da história. 2. ed. Rio de Janeiro: Forense Universitária, 2002.

CHABAL, Patrick et al. The postcolonial literature of lusophone Africa. London: Hurst \& Company, 1996.

CHAVES, Rita. A formação do romance angolano. São Paulo: Via Atlântica, 1999.

FERREIRA, Manuel. No reino de Caliban. Antologia panorâmica da poesia africana de expressão portuguesa. Cabo Verde, Guiné-Bissau, Angola, São Tomé e Príncipe e Moçambique. Lisboa: Seara Nova, 1974.

FOUCAULT, Michel. A ordem do discurso. Aula inaugural no Collège de France, pronunciada em 2 de dezembro de 1970. 3. ed. São Paulo: Loyola, 1996.

FOUCAULT, Michel. Estética: literatura e pintura, música e cinema. Rio de Janeiro: Forense Universitária, 2001.

GEERTZ, Clifford. O saber local. Novos ensaios em antropologia interpretativa. Petrópolis: Vozes, 1998.

HALL, Stuart. Da diáspora: identidades e mediações culturais. Belo Horizonte: Editora da UFMG; Brasília: Representação da UNESCO no Brasil, 2003.

HAMILTON, Russel G. Literatura Africana: literatura necessária. I - Angola. Lisboa: Edições 70, 1984.

HOBSBAWM, Eric; RANGER, Terence. A invenção das tradições, Rio de Janeiro: Paz e Terra, 1997.

HUTCHINSON, John \& SMITH, Anthony D. Nationalism. London: Oxford University Press, 1994.

LARANJEIRA, Pires. A negritude africana de língua portuguesa. Porto: Edições 
Afrontamento, 1995. (Colecção Textos / 29).

LE GOFF, Georges, 1984, “Memória”, em Memória-História, Enciclopédia Einaudi, Lisboa, Imprensa Nacional Casa da Moeda.

MARCON, Frank. Diálogos transatlânticos: identidade e nação entre Brasil e Angola, Florianópolis: Letras Contemporâneas, 2005.

MARCON, Frank. Retóricas de identidade e diferença na Lunda: narrativas coloniais e pós-coloniais na África Central. In: Afro-Ásia, Revista do CEAO, UFBA, n. 39. p. 9-33, 2010.

MATA, Inocência Luciano dos Santos. Ficção e história na obra de Pepetela: dimensão extratextual e eficácia. Dissertação (Doutorado em Literaturas Africanas de Expressão Portuguesa) - Faculdade de Letras da Universidade de Lisboa, 2003. NETO, Agostinho. Sobre a Cultura Nacional. Discurso realizado na tomada de posse do corpo dirigente da União, em 08 de janeiro de 1979. Angola, Luanda: EAL, 2003. PÉLISSIER, René. Histórias das Campanhas de Angola: resistência e revoltas, 18451941. Lisboa: Estampa, 1986. $2 \mathrm{v}$.

PEPETELA. [1980]. A revolta da casa dos ídolos. Lisboa: Edições 70, 1980. (Colecção Autores Angolanos).

PEPETELA. [1984]. Yaka. São Paulo: Ática, 1984. (Coleção Autores Africanos, 23). PEPETELA. [1989]. Lueji: o nascimento de um império. 3. ed. Lisboa: Publicações Dom Quixote, 1997. (Colecção Autores de Língua Portuguesa).

PEPETELA. [1992]. A geração da utopia. Rio de Janeiro: Nova Fronteira, 2000.

PEPETELA. [1997]. A gloriosa família: o tempo dos flamengos. Rio de Janeiro: Nova Fronteira, 1999.

SMITH, Anthony D. A identidade nacional. Lisboa: Gradiva, 1997.

WILLIAMS, Raymond. Cultura. 2. ed. Rio de Janeiro: Paz e Terra, 1992. 